\title{
Effects of time of insemination relative to ovulation, as determined by ultrasonography, on fertilization rate and accessory sperm count in sows
}

\author{
N. M. Soede, C. C. H. Wetzels, W. Zondag, M. A. I. de Koning and \\ B. Kemp
}

Wageningen Agricultural University, Department of Animal Husbandry, Marijkeweg 40, 6709 PG Wageningen. The Netherlands

\begin{abstract}
The effects of the timing of insemination relative to ovulation on fertilization rate, accessory sperm count and early embryo development were studied in sows. Oestrus detection was performed at intervals of $8 \mathrm{~h}$. Sows were artificially inseminated once with $3 \times 10^{9}$ spermatozoa. Transrectal ultrasonography was performed at intervals of $4 \mathrm{~h}$ to determine when ovulation occurred and sows were killed at $120 \pm 6 \mathrm{~h}$ after ovulation. For each insemination-ovulation interval of $8 \mathrm{~h}$, fertilization rates were as follows: $>48 \mathrm{~h}, 35 \%$ $(n=1) ; 48-40$ h, $51 \pm 36 \%(n=6) ; 40-32$ h, $54 \pm 36 \%(n=14) ; 32-24$ h, $79 \pm 32 \%(n=19)$; $24-16$ h, $94 \pm 11 \%(n=24) ; 16-8$ h, $92 \pm 21 \%(n=24) ; 8-0$ h, $95 \pm 22 \%(n=21)$ and for the sows that were inseminated after ovulation: 0 to $-8 \mathrm{~h}, 75 \pm 38 \%(n=26) ;-8$ to $-16 \mathrm{~h}, 74 \pm 43 \%(n=15)$ and $<-16 \mathrm{~h}, 0 \%(n=1)$. The median accessory sperm count differed among the groups from 1 (insemination $40-48 \mathrm{~h}$ before ovulation) to 126 (insemination $0-8 \mathrm{~h}$ after ovulation) $(P=0.0001)$. Within each $8 \mathrm{~h}$ time interval, the normal embryos from sows with less than $90 \%$ normal embryos were less developed and had a lower sperm count than did the normal embryos from sows with more than $90 \%$ normal embryos $(P<0.05)$. In conclusion, fertilization rate and the accessory sperm count of the normal embryos were dependent on the interval between insemination and ovulation; fertilization results were optimal when insemination took place between 0 and $24 \mathrm{~h}$ before ovulation. Partial fertilization occurred in all the insemination-ovulation time intervals, but the frequency differed among the time intervals. In every insemination-ovulation time interval of $8 \mathrm{~h}$ the between-sow variation of reproductive characteristics (fertilization rate, accessory sperm count, embryo development) was large. The reasons for this variability between sows are unclear.
\end{abstract}

\section{Introduction}

The optimal time at which insemination should take place relative to ovulation (insemination-ovulation interval) depends on the lifespan of a sufficient number of fertile spermatozoa to ensure fertilization, the speed of sperm transport and sperm capacitation and on the lifespan of oocytes. Despite the extensive use of artificial insemination in pigs, only limited data are available on the optimal time of insemination; until recently, only indirect data were obtained using oestrus (Willemse and Boender, 1967), or reproductive hormones (Helmond et al., 1986), as measures for ovulation, or data were obtained from gilts in which ovulation was induced by exogenous hormones (Dziuk, 1970). Estimates of the optimal time for insemination, relative to ovulation, vary between 6-18 h (Dziuk, 1970) and 13-28 h (Helmond et al., 1986). However, the latter estimate was based on an incorrect assumption of the timing of the increase in progesterone relative to ovulation. After correction,

Received 25 November 1994. their estimate of the optimal interval would be $0-15 \mathrm{~h}$ (Soede et al., 1994). Recently, data became available in which ovulation was assessed directly, using transcutaneous ultrasonography (Waberski et al., 1994a). In gilts that were inseminated once with $2 \times 10^{9}$ spermatozoa between $16 \mathrm{~h}$ before ovulation and $12 \mathrm{~h}$ after ovulation, the optimal insemination time was $0-12 \mathrm{~h}$ before ovulation.

The present experiment was undertaken to study the effects of varying the interval between (a single) insemination and ovulation (assessed by transrectal ultrasonography) on fertilization rate, early embryo development and accessory sperm count of prehatched embryos in a large group of multiparous sows.

\section{Materials and Methods}

Animals and housing

Every 2 weeks for a period of 8 months (19 occasions), an average of 10 sows was obtained at the day of weaning after 
$29 \pm 5(21-54)$ days of lactation. The sows were weaned at approximately $11: 00 \mathrm{~h}$ and immediately transported to the experimental farm $(70 \mathrm{~km})$. On arrival, the sows were housed individually and received approximately $2.5 \mathrm{~kg}$ of a commercial sow diet (12.9 MJ $\mathrm{ME} \mathrm{kg}^{-1}$ ) daily and water ad libitum. Only sows that ovulated between day 3 and day 8 after weaning were used. The number of sows from parity 1 to 5 was; 5,56 , 52,34 and 4, respectively. The sows were from three synthetic lines, which were parent lines for commercial crossbred sows (Dalland b.v., Mersselo, The Netherlands).

\section{Detection of oestrus}

Oestrus detection was performed at intervals of $8 \mathrm{~h}$ beginning approximately $62 \mathrm{~h}$ after weaning. A boar was taken to the sows and the back pressure test was performed in the presence of the boar. The time of onset of oestrus was defined as the first time a sow showed a standing response minus $4 \mathrm{~h}$. The end of oestrus was defined as the last time the sow showed a standing response plus $4 \mathrm{~h}$.

\section{Insemination}

At variable times from onset of oestrus, sows were taken to the boar pen and artificially inseminated once with a commercial dose of $3 \times 10^{9}$ mixed spermatozoa in the presence of the boar. The age of spermatozoa at insemination varied between $12 \mathrm{~h}$ and $38 \mathrm{~h}$ and was on average $23 \pm 5 \mathrm{~h}$. Sperm quality was assessed for three consecutive days at the Artificial Insemination Centre. Only good quality semen was used; the variability in sperm quality was very low.

\section{Detection of ovulation}

At approximately $70 \mathrm{~h}$ after weaning, transrectal ultrasonography was performed to check for the presence and size of follicles or corpora lutea. From $16 \mathrm{~h}$ after the onset of oestrus, transrectal ultrasonography was performed at intervals of $4 \mathrm{~h}$ to assess the moment of ovulation. An annular array sector scanner (type $150 \mathrm{~V}$, Pie Medical b.v., Maastricht) with a 5.0-7.5 MHz multiple scan angle transducer was used. During scanning, the presence or absence of preovulatory follicles (diameter of antrum $>4 \mathrm{~mm}$ ) was determined. Time of ovulation was defined as the first time that no follicles were counted minus $2 \mathrm{~h}$. When the number of follicles was not zero, but noticeably lower than before, ovulation was assumed to have just started $(t=0)$, since ovulation, thus assessed, takes on average $2 \mathrm{~h}$ in spontaneously ovulating sows (Soede et al., 1992). Ovulation was confirmed by an additional scanning $4 \mathrm{~h}$ later. Frequent scanning around ovulation has no apparent effect on fertilization (Soede and Kemp, 1993).

\section{Development of embryos}

Sows were killed $120 \pm 6(106-136) \mathrm{h}$ after ovulation. The number of corpora lutea was counted on both ovaries. Each oviduct was flushed with $15 \mathrm{ml}$ Dulbecco's PBS (DPBS) from the infundibulum into the uterus. The oviduct was separated from the uterus and each uterine horn was flushed twice with
$30 \mathrm{ml}$ DPBS to collect the embryos and oocytes. Recovery rate was determined as the percentage of embryos and oocytes recovered based on the number of corpora lutea. The quality and morphology of the recovered embryos and oocytes was assessed (magnification $\times 60$ ). Embryos and oocytes were then subjected to hypotonic treatment $\left(0.6 \% \mathrm{w} / \mathrm{v} \mathrm{KCl}, 0^{\circ} \mathrm{C}, 10 \mathrm{~min}\right)$ and subsequently placed on a fat-free glass slide. Small droplets of methanol/acetic acid (3/1 v/v) were added until disruption and spreading of the embryo (generally $1 \mathrm{~cm}^{2}$ ), to allow the nuclei and spermatozoa to be counted using a microscope (magnification $\times 200$ ) after drying and staining with $10 \%$ Giemsa in PBS. An oocyte was classed as unfertilized if the nuclei count was zero or one. Embryos with a degenerated morphology and a low number of nuclei were classed as degenerate; the remaining embryos were considered normal. Fertilization rate and the rate of normal and degenerating embryos were determined on the basis of the total number of recovered embryos and oocytes.

\section{Statistical analyses}

Data were analysed using SAS (1990). The GLM procedure was used to analyse effects of the insemination-ovulation interval, as periods of $8 \mathrm{~h}$, on embryo status (unfertilized, degenerated and normal embryos per litter) after arcsine transformation of the proportions of unfertilized, degenerate and normal embryos (Snedecor and Cochran, 1989). Sows were divided into 'good' sows: more than $90 \%$ normal embryos; and 'poor' sows: $90 \%$ or less than $90 \%$ normal embryos. This division was based partly on the frequency distribution of the percentage of normal embryos per litter: $0 \%(n=18)$, $>0-10 \%(n=2),>10-20 \%(n=1),>20-30 \%(n=5),>30-$ $40 \%(n=3),>40-50 \%(n=3),>50-60 \%(n=4),>60-70 \%$ $(n=4),>70-80 \%(n=7),>80-90 \%(n=12),>90-100 \%$ $(n=24)$ and $100 \%(n=67)$. Preliminary analyses of the data (not published) showed that a division between 'good' and 'poor' sows at $80 \%$ or at $90 \%$ lead to similar conclusions. The division at $90 \%$ makes sure that 'good' sows have at most two abnormal embryos. Embryonic age was defined as time between ovulation and death for sows that were inseminated before ovulation. For sows that were inseminated at or after ovulation, embryonic age was defined as the time between insemination and death. Embryonic age, thus defined, does not take into account the time taken for gametes to reach the site of fertilization (oocytes and spermatozoa), nor does it take into account the time taken for penetration of all oocytes. Hunter and Dziuk (1968) found accessory sperm cells in oocytes within $2 \mathrm{~h}$ of insemination in gilts that had been inseminated at the expected moment of ovulation. This finding indicates that both oocyte and sperm transport may take less than $2 \mathrm{~h}$. Therefore although embryonic age does not start at exactly the time of ovulation or insemination, the difference is considered to be not more than a few hours.

Embryo development was analysed taking into account only normal embryos. Differences in numbers of accessory spermatozoa of the normal embryos between the inseminationovulation interval periods of $8 \mathrm{~h}$ were analysed using the Wilcoxon test of the NPARIWAY procedure. Relationships between age of spermatozoa at insemination and embryo 
Table 1. Parameters of oestrus and ovulation of 151 sows that ovulated between day 3 and day 7 after weaning ${ }^{\mathrm{a}}$

\begin{tabular}{lcc}
\hline Parameter & Mean \pm SD & Range \\
\hline Oestrus & & $65-153$ \\
$\quad$ Weaning to oestrus interval $(\mathrm{h})$ & $93 \pm 18$ & $24-88$ \\
$\quad$ Duration of oestrus $(\mathrm{h})$ & $50 \pm 13$ & $10^{\mathrm{b}}-58$ \\
Ovulation & $35 \pm 8$ & $39-133$ \\
$\quad$ Onset of oestrus to ovulation $(\mathrm{h})$ & $72 \pm 15$ & $-3-60$ \\
$\quad$ Relative moment of ovulation during oestrus $(\%)$ & $22 \pm 15$ & $-19-51$ \\
Insemination & $12 \pm 16$ & $12-38$ \\
$\quad$ Onset of oestrus relative to insemination $(\mathrm{h})$ & $23 \pm 5$ & 5 \\
$\quad$ Insemination to ovulation interval $(\mathrm{h})$ & & \\
$\quad$ Age of spermatozoa at insemination $(\mathrm{h})$ & &
\end{tabular}

${ }^{a}$ Seven sows showed oestrus within $62 \mathrm{~h}$ from weaning; onset of oestrus is therefore unknown.

${ }^{\mathrm{b}}$ A number of sows that showed oestrus relatively late after weaning were scanned for ovulation from onset of oestrus onwards. One of these sows ovulated within $16 \mathrm{~h}$ from onset of oestrus, that is, $10 \mathrm{~h}$ after onset of oestrus.

status on accessory sperm count were analysed. In these analyses, sperm age was taken either as two age classes of $24 \mathrm{~h}$ or as a covariable (linear component) and the time between insemination and ovulation was taken into account as periods of $8 \mathrm{~h}$.

\section{Results}

\section{Animals}

Of the 198 sows obtained, 47 sows were excluded from the experiment; 14 sows $(7 \%)$ showed lactational oestrus (corpora lutea at day 3$), 9$ sows $(4.5 \%)$ ovulated within $16 \mathrm{~h}$ from onset of oestrus, 6 sows $(3 \%)$ had cystic ovaries at day 8,5 sows $(2.5 \%)$ ovulated within 3 days from weaning, 5 sows $(2.5 \%)$ had a silent oestrus (corpora lutea at day 8 ), 2 sows ( $1 \%$ ) had inactive ovaries at day 8,2 sows $(1 \%)$ were too narrow to use transrectal ultrasonography, 1 sow $(0.5 \%)$ was lame, 1 sow $(0.5 \%)$ had a urinary infection, I sow $(0.5 \%)$ appeared to have only one uterine horn and 1 sow $(0.5 \%)$ had a uterine infection. Therefore, 151 sows $(76 \%)$ were used for the experiment. The occurrence of lactational oestrus was not related to the duration of lactation or the number of piglets weaned $(P>0.05)$. The genetic background of the sows did not affect any of the parameters $(P>0.05)$.

\section{Oestrus and ovulation}

In the remaining 151 sows, oestrus lasted on average $50 \mathrm{~h}$ but varied between 24 and $88 \mathrm{~h}$ (Table 1). Ovulation took place between 10 and $58 \mathrm{~h}$ after the onset of oestrus. Sows were inseminated at different times from onset of oestrus $(-3$ to $60 \mathrm{~h}$ ) and from ovulation (between $51 \mathrm{~h}$ before ovulation and $19 \mathrm{~h}$ after ovulation). The time of ovulation during oestrus (OV) was dependent on the duration of oestrus (OEST) $O V=11.1+0.48 \times O E S T\left(R^{2}=0.60, P=0.0001, n=144\right.$ : see Fig. 1). Only 5 of the 144 sows ovulated before $50 \%$ of the oestrous period and only 6 of the 144 sows ovulated after oestrus. On average, sows ovulated at $72 \%$ of the oestrous period (Table 1).

\section{Embryo recovery}

Sows had a mean ( $\pm \mathrm{SD}$ ) of $22 \pm 4$ corpora lutea (Table 2 ), from which $84 \pm 11 \%$ embryos and oocytes were recovered. Recovery rate was not related to the percentage of unfertilized, degenerating or normal embryos per sow $(P>0.10)$. The status of the embryos and oocytes varied considerably between sows and fertilization rate differed between $0 \%$ and $100 \%$. Most fertilized oocytes had a normal appearance; only about $4 \%$ of embryos were degenerate. Development of the normal embryos varied considerably from 3.1 to 7.0 cell cycles. This variation in embryo development between litters is related to the variation in age of the litters $(A G E)$; Cell cycles $=-3.00+0.072 \times A G E\left(R^{2}=0.42, P<0.001, n=133\right)$.

\section{Insemination-ovulation interval: embryo status}

The effects of the interval between insemination and ovulation on fertilization rate and the percentage of normal and degenerated embryos are shown (Table 3). Within each insemination-ovulation interval of $8 \mathrm{~h}$, the variability between sows was very large; in nearly all groups, fertilization rate and consequently the percentage of normal embryos per litter varied between $0 \%$ and $100 \%$. However, despite this variability within the $8 \mathrm{~h}$ groups, there were clear differences between the groups. When insemination took place between 0 and $24 \mathrm{~h}$ before ovulation, the percentage of normal embryos was significantly higher compared with the percentage when insemination takes place before or after this period. However, normal fertilization did still occur when insemination took place more than $40 \mathrm{~h}$ before ovulation or more than $8 \mathrm{~h}$ after ovulation as is shown by the occurrence of litters with a high percentage of normal embryos in these groups. Partial fertilization occurs in all the insemination-ovulation time intervals in, on average, $36 \%$ of litters; however, the incidence is lowest when insemination takes place between 0 and $8 \mathrm{~h}$ 


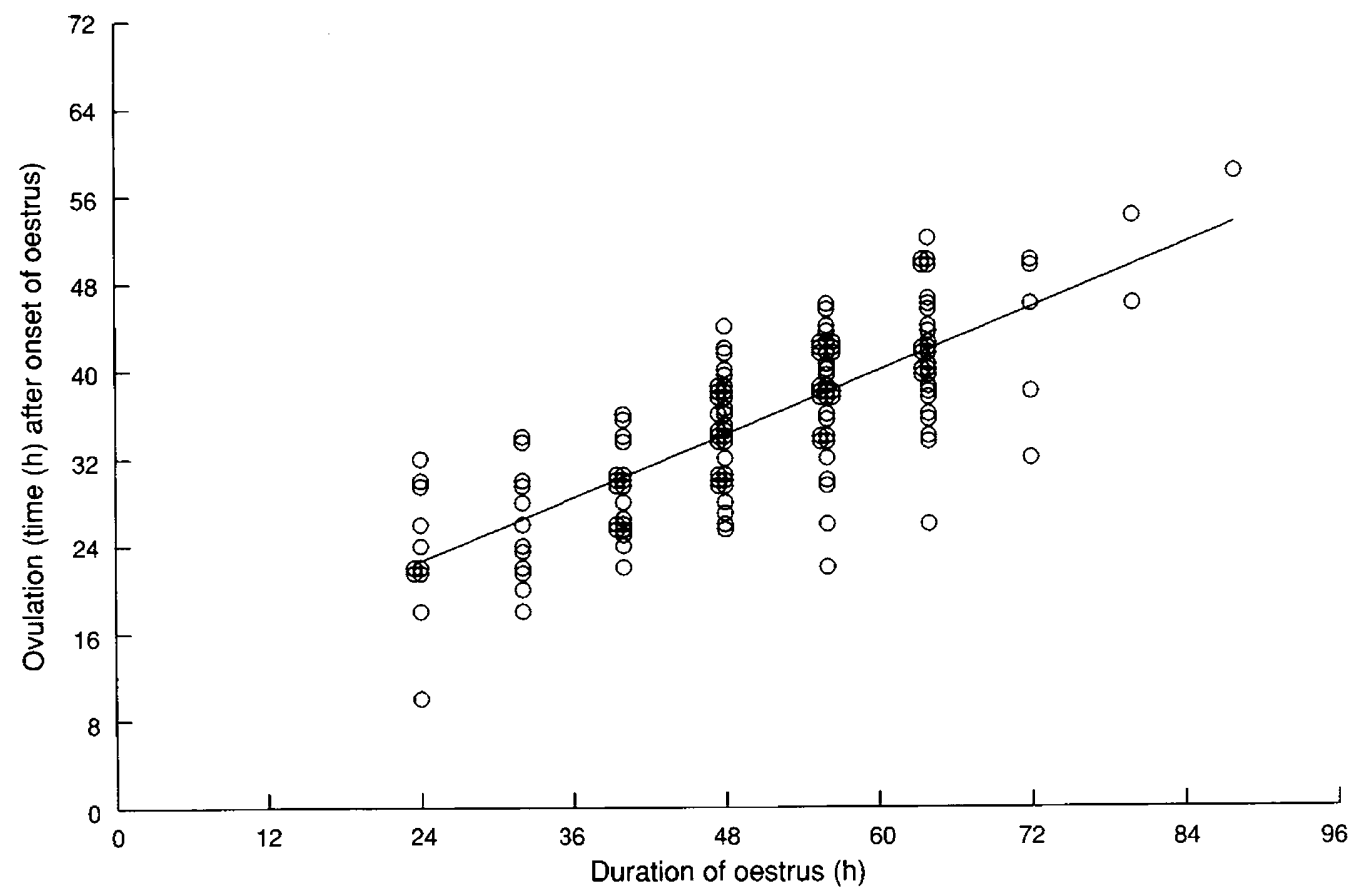

Fig. 1. Time of ovulation (OV) during oestrus (OEST) in multiparous sows; $O V=11.1+0.48 \times O E S T$ $\left(R^{2}=0.60, P=0.0001, n=144\right)$.

Table 2. Embryo parameters for 151 sows killed $120 \pm 6 \mathrm{~h}$ after ovulation

\begin{tabular}{lcc}
\hline Parameter & Mean \pm SD & Range \\
\hline Corpora lutea $(n)$ & $22 \pm 4$ & $12-31$ \\
Embryos and oocytes $\quad$ & \\
$\quad$ recovered $(n)$ & $18 \pm 4$ & $8-30$ \\
recovered (\%) & $84 \pm 11$ & $47-100$ \\
status unfertilized (\%) $\quad 21 \pm 33$ & $0-100$ \\
$\quad 4$ degenerated $(\%)$ & $4 \pm 8$ & $0-44$ \\
$\quad$ normal $(\%)$ & $76 \pm 36$ & $0-100$ \\
Age of embryos & $118 \pm 7$ & $98-136$ \\
Embryo development of the normal embryos & $56 \pm 26$ & $10-183$ \\
$\quad$ nuclei $(n)$ & $5.5 \pm 0.8$ & $3.1-7.0$ \\
$\quad$ cell cycles $(n)$ & $57 \pm 77$ & $0-397$ \\
Accessory sperm cells of the normal embryos $(n)$ & &
\end{tabular}

${ }^{\mathrm{a}}$ On the basis of morphology and nuclei count, embryos and oocytes were classified as unfertilized oocytes, degenerated embryos or normal embryos.

before ovulation and increases with earlier and later inseminations (Fig. 2).

\section{Insemination-ovulation interval: embryo development}

Development of the normal embryos was not influenced by the insemination-ovulation interval $(P>0.10)$. However, in each class of insemination-ovulation intervals, embryos from sows with $90 \%$ or more normal embryos consistently showed better development compared with those from sows with less than $90 \%$ normal embryos. On average, development in terms of number of cell cycles was $5.7 \pm 0.7(3.2-7.0)$ for the 'good' sows and 5.1 $\pm 0.8(3.1-6.6)$ for the 'poor' sows $(P<0.001$ (age corrected)).

\section{Insemination-ovulation interval: accessory sperm count}

The median of the average accessory sperm count of the normal embryos per litter was 25 (132 litters, varying from 0 to 397) and was influenced by the time between insemination and ovulation (Table 4). The count was highest for animals that were inseminated between $8 \mathrm{~h}$ before ovulation and $8 \mathrm{~h}$ after ovulation; median number of sperm cells for these classes were 108 and 126, respectively. The accessory sperm count is 
Table 3. Status of the recovered embryos and oocytes per sow for each insemination-ovulation time interval of $8 \mathrm{~h}(n=151)$ presented as the retransformed values of the mean of the arcsine transformed values

\begin{tabular}{|c|c|c|c|c|c|c|}
\hline & \multirow[b]{2}{*}{ Sows $(n)$} & \multicolumn{4}{|c|}{ Embryo status per sow (\%) } & \multirow{2}{*}{$\begin{array}{c}\text { Number }(\%) \text { of } \\
\text { sows with }>90 \% \\
\text { normal embryos }\end{array}$} \\
\hline & & $\begin{array}{c}\text { Unfertilized } \\
\text { oocytes }\end{array}$ & Deg & $\begin{array}{l}\text { enerated } \\
\text { nbryos }\end{array}$ & $\begin{array}{l}\text { Normal } \\
\text { embryos }\end{array}$ & \\
\hline \multicolumn{7}{|c|}{ Insemination before ovulation (h) } \\
\hline$\geq 48$ & 1 & 65 & & 6 & 29 & $0 \quad(0)$ \\
\hline$\geq 40-48$ & 6 & $\begin{array}{c}49^{c e} \\
58(0-100)\end{array}$ & & $\begin{array}{l}8^{\mathrm{a}} \\
(0-40)\end{array}$ & 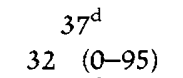 & $1(17)$ \\
\hline$\geq 32-40$ & 14 & $\begin{array}{c}45^{\mathrm{c}} \\
50(0-100)\end{array}$ & & $\begin{array}{l}5 \\
(0-44)\end{array}$ & $44^{47^{d}}(0-100)$ & $2(14)$ \\
\hline$\geq 24-<32$ & 19 & $\begin{array}{c}15^{\mathrm{ab}} \\
0(0-100)\end{array}$ & 0 & $\begin{array}{l}4 \\
(0-27)\end{array}$ & $\begin{array}{c}79^{\mathrm{abc}} \\
87 \quad(0-100)\end{array}$ & $9(47)$ \\
\hline$\geq 16<24$ & 24 & $\begin{array}{c}4^{a} \\
0(0-40)\end{array}$ & 0 & $\begin{array}{l}3^{\mathrm{b}} \\
(0-40)\end{array}$ & $\begin{array}{c}94^{\mathrm{a}} \\
100(20-100)\end{array}$ & $19(79)$ \\
\hline$\geq 8-16$ & 24 & $\begin{array}{c}6^{\text {ad }} \\
0(0-100)\end{array}$ & 0 & $\begin{array}{l}2^{b} \\
(0-13)\end{array}$ & $100 \quad(0-100)$ & $20(83)$ \\
\hline$\geq 0<<$ & 21 & $\begin{array}{c}4^{\mathrm{a}} \\
0(0-100)\end{array}$ & 0 & $\begin{array}{l}2^{b} \\
(0-11)\end{array}$ & $100 \quad(0-100)$ & $18(86)$ \\
\hline \multicolumn{7}{|c|}{ Insemination after ovulation (h) } \\
\hline$\geq-8-0$ & 26 & $\begin{array}{c}19^{\text {bcde }} \\
0(0-100)\end{array}$ & 0 & $\begin{array}{l}4 \\
(0-38)\end{array}$ & $\begin{array}{c}75^{\text {be }} \\
95 \quad(0-100)\end{array}$ & $14(54)$ \\
\hline$\geq-16<-8$ & 15 & $\begin{array}{l}33^{b c} \\
6(0-100)\end{array}$ & 0 & $\begin{array}{l}4 \\
(0-22)\end{array}$ & $\begin{array}{c}62^{\mathrm{ce}} \\
76 \quad(0-100)\end{array}$ & $8(53)$ \\
\hline$<-16$ & 1 & 100 & & 0 & 0 & $0 \quad(0)$ \\
\hline
\end{tabular}

Median and range are given in parentheses.

abcde Values with different letters in a column differ significantly $(P<0.05)$. Sows that were inseminated more than $48 \mathrm{~h}$ before ovulation and more than $16 \mathrm{~h}$ after ovulation are not included in the analyses.

significantly higher in the 'good' sows ( $\geq 90 \%$ normal embryos) compared with the 'poor' sows when insemination takes place between 16 and $40 \mathrm{~h}$ before ovulation (Table 4 ). In all other periods, the accessory sperm count was also higher in the 'good' sows, but the difference was not significant. The median of the average accessory sperm counts of degenerated embryos per litter was 2 (41 litters, average sperm count varied between 0 and 374 ) and tended to differ between the insemination-ovulation time intervals $(P<0.10)$. The median of the average accessory sperm count of the unfertilized oocytes was 0 (67 litters, the average sperm count varied between 0 and 164) and was not different between the insemination-ovulation time intervals.

\section{Age of spermatozoa}

The age of the spermatozoa, either taken as a continuous parameter $(12-38 \mathrm{~h})$ or taken as two classes $(0-24 \mathrm{~h}$ and $>24 \mathrm{~h}$ ), was not related to fertilization rate, the percentage of normal embryos or the accessory sperm count within or between the insemination-ovulation time intervals $(P<0.05)$.

\section{Discussion}

In this experiment, multiparous sows were inseminated with $3 \times 10^{9}$ spermatozoa between day 4 and day 8 after weaning, and ovulation was assessed using transrectal ultrasonography. Fertilization results were judged by the fertilization rate per sow, the percentage of normal developing embryos per litter and the average accessory sperm count of the normal embryos per litter. The results were very variable. Fertilization rate and the percentage of normal embryos per sow varied from $0 \%$ to $100 \%$ and the average accessory sperm count varied from 0 to 397. A large part of this variability was related to the interval between insemination and ovulation; when insemination took place between 0 and $24 \mathrm{~h}$ before ovulation, unfertilized oocytes represented fewer than $10 \%$ of the embryos and oocytes, whereas insemination more than $24 \mathrm{~h}$ before ovulation, or after ovulation, resulted in more than $25 \%$ unfertilized oocytes. Degenerating embryos represented only $4 \%$ of the oocytes and embryos and their occurrence was not related to the timing of insemination relative to ovulation. Consequently, the percentage of normal embryos is approximately the same as fertilization rate. The percentage of normal embryos is highest when insemination takes place between 0 and $24 \mathrm{~h}$ before ovulation. However, the variability in fertilization results between sows was large for all the insemination-ovulation intervals. Successful fertilization ( $>90 \%$ normal embryos) was associated with better embryo development and higher accessory sperm counts, irrespective of the timing of insemination relative to ovulation. Sperm age varied from 12 to $38 \mathrm{~h}$ and did not affect these parameters. Theoretically, the variability in fertilization results (fertilization rate, accessory sperm count) between sows 


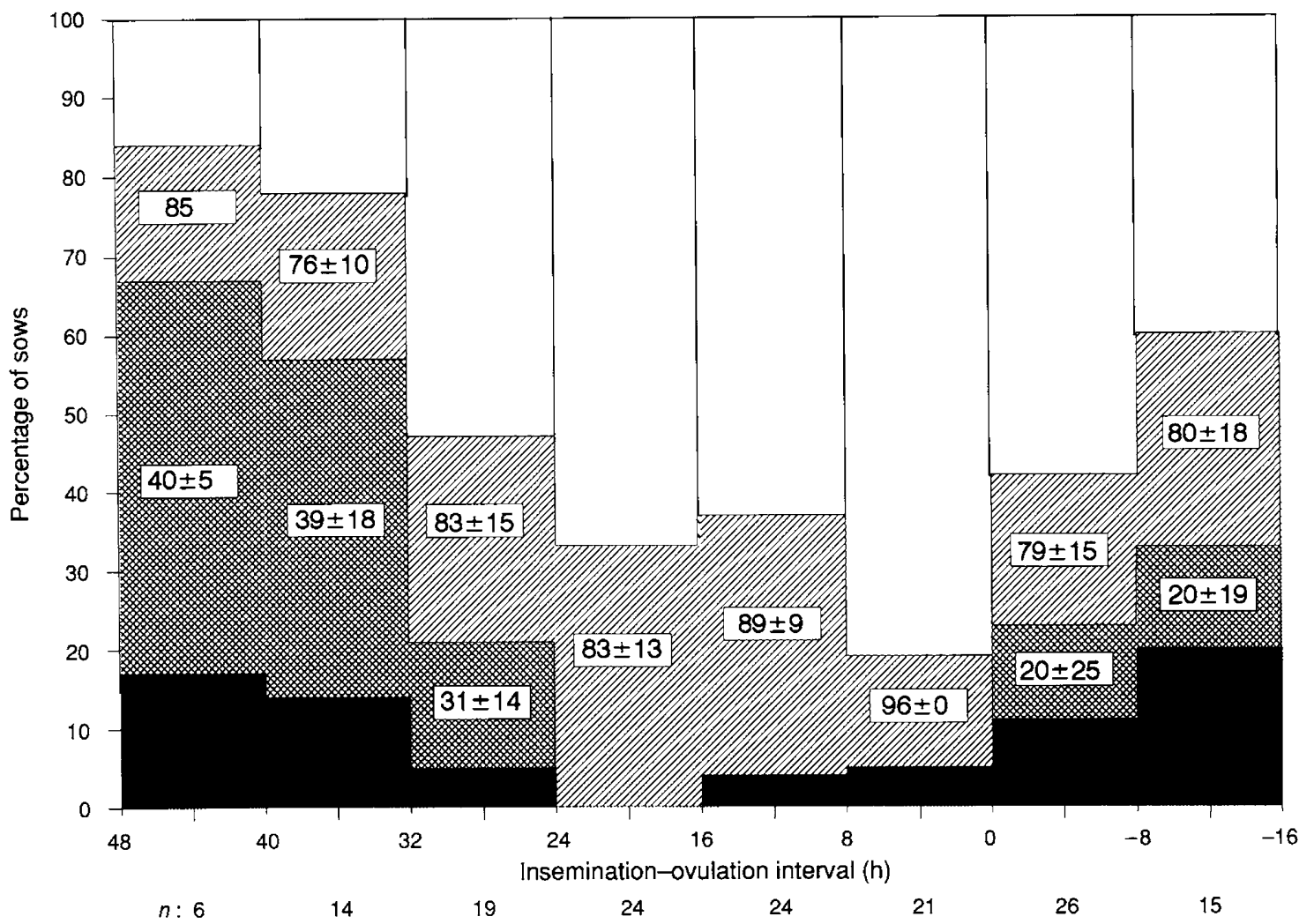

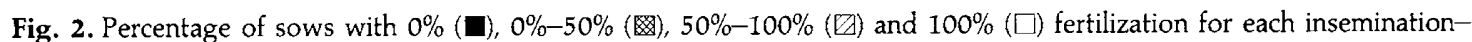
ovulation 8 -h time interval $(n=151)$. For sows with partial fertilization, mean fertilization rate (mean \pm SD) is given per time interval.

Table 4. Median and range (in parentheses) of the number of accessory sperm cells of the normal embryos per sow for each $8 \mathrm{~h}$ interval between insemination and ovulation $(n=132)$

\begin{tabular}{|c|c|c|c|c|}
\hline & \multicolumn{3}{|c|}{ Accessory sperm count } & \multirow[b]{2}{*}{$P^{\mathrm{a}}$} \\
\hline & $\begin{array}{c}\text { Sows with }>90 \% \\
\text { normal embryos }\end{array}$ & $\begin{array}{c}\text { Sows with } \leq 90 \% \\
\text { normal embryos }\end{array}$ & All sows & \\
\hline \multicolumn{5}{|c|}{ Insemination before ovulation (h) } \\
\hline$\geq 48$ & 一 & 0 & 0 & \\
\hline$\geq 40-<48$ & 7 & $0 \quad(0-2)$ & $1(0-7)$ & NS \\
\hline$\geq 32-<40$ & $7 \quad(3-10)$ & $0 \quad(0-6)$ & $1 \quad(0-10)$ & $*$ \\
\hline$\geq 24<32$ & $15 \quad(3-53)$ & $2(0-25)$ & $8(0-53)$ & $* *$ \\
\hline$\geq 16-<24$ & $16(1-95)$ & $3(0-9)$ & $8 \quad(0-95)$ & $*$ \\
\hline$\geq 8<16$ & $31 \quad(2-246)$ & $3 \quad(2-28)$ & $28 \quad(2-246)$ & NS \\
\hline$\geq 0<8$ & $114(12-300)$ & $44(26-61)$ & $108(12-300)$ & NS \\
\hline \multicolumn{5}{|c|}{ Insemination after ovulation (h) } \\
\hline$\geq-8<0$ & $130 \quad(2-279)$ & $31 \quad(1-270)$ & $126(1-279)$ & NS \\
\hline$\geq-16<-8$ & $91(17-397)$ & $14 \quad(3-303)$ & $70 \quad(3-397)$ & NS \\
\hline$<-16$ & - & - & - & \\
\hline
\end{tabular}

aSignificance of differences in accessory sperm count between sows with $<90 \%$ and $\geq 90 \%$ normal embryos tested on rank numbers with Kruskal-Wallis. NS: $P>0.10 ; * P<0.05 ;{ }^{*} P<0.01$.

for a certain interval between insemination and ovulation may be related to variability in parameters such as the fertile lifespan of sperm cells and oocytes, the binding of sperm cells to oocytes, sperm losses or the capacity or lifespan of the sperm reservoir. Sows in which insemination took place between
24 and $32 \mathrm{~h}$ before ovulation or 0 to $8 \mathrm{~h}$ after ovulation are of special interest as successful fertilization occurred in approximately $50 \%$ of the cases. Further study of these intervals will increase our knowledge of the process of fertilization and of differences between sows. 
When the interval between insemination and ovulation is greater than (generally) $24 \mathrm{~h}$, apparently too few fertile sperm cells are present at the site of fertilization. This is indicated by the low numbers of accessory sperm cells in the embryos. Estimates of the fertile lifespan of spermatozoa (up to $48 \mathrm{~h}$ ) have often been based on the presence of motile spermatozoa in the oviduct either after natural mating (Fléchon and Hunter, 1981) or after artificial insemination with $40 \times 10^{9}$ spermatozoa (Rigby, 1966; First et al., 1968). It is unclear how the presence of motile sperm cells is related to the fertilizing capacity of the spermatozoa. On the basis of fertilization results at 1-3 days after ovulation, Hunter (1984) concluded that viable spermatozoa could be arrested in the oviduct for more than $36 \mathrm{~h}$ after natural mating. In agreement with this, we found that, although optimal fertilization results are found when the interval between insemination ( $3 \times 10^{9}$ spermatozoa) and ovulation is less than $24 \mathrm{~h}$, spermatozoa can fertilize normally for more than $40 \mathrm{~h}$ after insemination. When insemination takes place after ovulation, large numbers of fertile spermatozoa are present at the site of fertilization, as shown by the large numbers of accessory sperm cells, even in sows with poor fertilization results. After (induced) ovulation, it is the ageing of the oocytes, not the lack of fertile spermatozoa, that causes low fertilization rates and the increase in the rate of polyspermic fertilization (Hunter, 1967). The time at which the degenerative effects of oocyte ageing become apparent has been estimated as approximately 8-12 h after ovulation in pigs (Hunter, 1967, 1994; Hunter and Dziuk, 1968). However, this time point may be variable from sow to sow. In the present experiment, some litters consisted of $100 \%$ normal embryos when insemination took place $14 \mathrm{~h}$ after ovulation.

In the work reported here, good fertilization results were found with insemination up to $24 \mathrm{~h}$ before ovulation. This is considerably longer than the $12 \mathrm{~h}$ found by Waberski et al. (1994a) who used transcutaneous ultrasonography to assess ovulation and inseminated gilts with $2 \times 10^{9}$ spermatozoa. In their study, however, only five gilts were inseminated between 12 and $16 \mathrm{~h}$ before ovulation and no gilts were inseminated more than $16 \mathrm{~h}$ before ovulation. Their estimate of optimal insemination-ovulation intervals may therefore not be very accurate owing to the few animals that were inseminated more than $12 \mathrm{~h}$ before ovulation. It is also possible that the use of lower numbers of spermatozoa causes a shorter range of optimal intervals between insemination and ovulation; Baker et al. (1968) showed that fertilization rates fell (to approximately $10 \%$ from approximately $60 \%$ ) when a low sperm number $\left(1 \times 10^{9}\right.$ versus $5 \times 10^{9}$ spermatozoa) was used for insemination. It is unclear whether this $24 \mathrm{~h}$ optimal range of insemination-ovulation interval is longer under conditions of natural mating; during natural mating, between $30 \times 10^{9}$ and $60 \times 10^{9}$ spermatozoa are deposited in the female reproductive tract (Garner and Hafez, 1993), that is, between 10 and 20 times the number at artificial insemination. However, it is possible that the limiting factor is not sperm number but sperm survival. Waberski et al. (1994b) showed that insemination with older spermatozoa (stored at $17^{\circ} \mathrm{C}$ in a BTS extender for more than $48 \mathrm{~h}$ ) shortens the optimal range of inseminationovulation intervals. It is unclear whether storage of spermatozoa in the female reproductive tract affects sperm survival similarly.
It is generally assumed that fertilization is an 'all or none' phenomenon; either all oocytes are fertilized or none (see Hunter, 1994). This study clearly showed that partial fertilization frequently occurs, even when the timing of insemination relative to ovulation is optimal. This finding is of importance for research on embryo survival, as embryo survival is normally defined as the number of embryos related to the number of corpora lutea and assumes that the fertilization rate is $100 \%$.

The moment of ovulation during oestrus is strongly related to the duration of oestrus. Ovulation takes place after approximately $70 \%$ of the oestrous period. This phenomenon has been described in a number of recent publications in which ultrasonography was used to study the time of ovulation (Soede et al., 1992, 1994; Weitze et al., 1994) and opposes the idea that ovulation takes place at a constant interval from onset of oestrus (Hunter, 1994).

In conclusion, the time of ovulation after onset of oestrus is variable, but the relative timing of ovulation during oestrus is more constant. Fertilization results are strongly related to the interval between insemination and ovulation; the period between 0 and $24 \mathrm{~h}$ before ovulation gives optimal fertilization results. Outside this period, differences between sows become more apparent in terms of successful fertilizations, embryo development and number of accessory sperm cells. The causes of these differences between sows need further study. This study, furthermore, clearly showed that partial fertilization occurs frequently, even in sows that appear to be inseminated at an optimal time relative to ovulation.

The authors gratefully acknowledge the financial support of the Dutch Association of Artificial Insemination Centres for pigs and the assistance of W. Hazeleger, A. de Bye, B. Muller and J. Busscher.

\section{References}

Baker RD, Dziuk PJ and Norton HW (1968) Effect of volume of semen, number of sperm and drugs on transport of sperm in artificially inseminated gilts Joumal of Animal Science 27 88-93

Dziuk P (1970) Estimation of optimum time for insemination of gilts and ewes by double mating at certain times relative to ovulation Journal of Reproduction and Fertility 22 277-282

First NL, Short RE, Peters JP and Stratman FW (1968) Transport and loss of boar spermatozoa in the reproductive tract of the sow Journal of Animal Science 27 1037-1040

Fléchon JE and Hunter RHF (1981) Distribution of spermatozoa in the uterotubal junction and isthmus of pigs, and their relationship with the luminal epithelium after mating: a scanning electron microscope study Tissue and Cell 13 127-139

Garner DL and Hafez ESE (1993) Spermatozoa and seminal plasma. In Reproduction in Farm Animals (6th Edn) pp 165-187 Ed. ESE Hafez. Lea and Febiger, Philadelphia

Helmond FA, Aarnink A and Oudenaarden C (1986) Periovulatory hormone profiles in relation to embryonic development and mortality in pigs. In Embryonic Mortality in Farm Animals pp 119-125 Eds JM Sreenan and MG Diskin. Martinus Nijhoff, Dordrecht

Hunter RHF (1967) The effects of delayed insemination on fertilization and early cleavage in the pig Journal of Reproduction and Fertility 13 133-147

Hunter RHF (1984) Pre-ovulatory arrest and peri-ovulatory redistribution of competent spermatozoa in the isthmus of the pig oviduct Journal of Reproduction and Fertility 72 203-211

Hunter RHF (1994) Causes for failure of fertilization in domestic species. In Embryonic Mortality in Domestic Species pp 1-22 Eds MT Zavy and RD Geisert. CRC Press, Inc., Boca Raton 
Hunter RHF and Dziuk PJ (1968) Sperm penetration of pig eggs in relation to the timing of ovulation and insemination Journal of Reproduction and Fertility 15 199-208

Rigby JP (1966) The persistence of spermatozoa at the uterotubal junction of the sow Journal of Reproduction and Fertility 11 153-155

SASISTAT (1990) Users's guide, SAS institute, Cary, NC

Snedecor GW and Cochran WG (1989) Statistical Methods (8th Edn) lowa State University Press, Ames

Soede NM and Kemp B (1993) In synchronized pigs, the duration of ovulation is not affected by insemination and is not a determinant for early embryonic diversity Theriogenology 39 1043-1053

Soede NM, Noordhuizen JPTM and Kemp B (1992) The duration of ovulation in pigs, studied by transrectal ultrasonography, is not related to early embryonic diversity Theriogenology 38 653-666

Soede NM, Helmond FA and Kemp B (1994) Periovulatory profiles of oestradiol, LH and progesterone in relation to oestrus and embryo mortality in multiparous sows using transrectal ultrasonography to detect ovulation Journal of Reproduction and Fertility 101 633-641

Waberski D, Weitze KF, Gleumes T, Schwarz M, Willmen T and Petzoldt R (1994a) Effect of time of insemination relative to ovulation on fertility with liquid and frozen boar semen Theriogenology 42 831-840

Waberski D, Weitze KF, Lietmann C, Lübbert zur Lage W, Bortolozzo FP, Willmen T and Petzoldt R (1994b) The initial fertilizing capacity of long-term-stored liquid boar semen following pre- and postovulatory insemination Theriogenology 41 1367-1377

Weitze KF, Wagner-Rietschel H, Waberski D, Richter L and Krieter J (1994) The onset of heat after weaning, heat duration, and ovulation as major factors in Al timing in sows Reproduction in Domestic Animals 29 433-443

Willemse AH and Boender J (1967) The relation between the time of insemination and fertility in gilts Tijdschrift Diergeneeskunde 92 18-34 